\title{
EFFECTIVENESS OF ZAKAT-BASED PROGRAMS ON POVERTY ALLEVIATION AND ECONOMIC EMPOWERMENT OF POOR WOMEN: A CASE STUDY OF BANGLADESH
}

\author{
Fahami Muhammad Anis ${ }^{1}$ \\ Salina H. Kassim ${ }^{2}$
}

\begin{abstract}
Among the many problems facing Bangladesh, poverty remains a key problem affecting millions of lives. During the past few decades, many initiatives have been implemented such as microcredit and cash transfer programs, yet the results seemed to be ambiguous. New frontiers are now sought to find new sources of finance which could offer a more effective and sustainable solution to the root cause of the poverty problem. Considering the idea of entrepreneurship and group-based development approach of microcredit, a zakat-based development approach was initiated in Bangladesh at a private level by an organization called Center for Zakat Management (CZM) for poverty alleviation and sustainable economic empowerment targeting poor women in rural areas. This paper aims to assess the effectiveness of the CZM efforts in utilizing zakat funds for promoting entrepreneurship among poor rural women. Focusing on the case of Bangladesh, this study assesses the effectiveness of zakat on aspects such as income, house hold expense and fixed asset accumulation of the poor client based on the "before and after" approach. Groups comprising of poor individuals and families are given equity capital/seed money and are encouraged to embark on small businesses according to their own liking. The groups are supervised for a period of a minimum of three years to ensure all individuals within the group are able to continue with their activities and ultimately, free themselves from the shackles of poverty and graduate into sustainable livelihood. Results indicate a significant nominal and real increase in average monthly income, increase in fixed assets and an increase in monthly average household expenditure before and after receiving zakat money. Results also demonstrate factors such as age of the entrepreneur, family size, type of business involved and the amount of zakat received to have a strong influence in determining the success of women entrepreneurs. Education level of the entrepreneur, on the other hand, does not seem to have significant impact on the success or failure of the entrepreneur. The findings from this paper shed light on the effectiveness of zakat-based approach in alleviating poverty and ensuring sustainable economic empowerment of the poor rural women.
\end{abstract}

1 Phd Candidate Institute of Islamic Banking and Finance International Islamic University M alaysia 50728, Kuala Lumpur, M alaysia. Email: fahami.anis@live.iium.edu.my

2 Associate Professor Institute of Islamic Banking and Finance, International Islamic University Malaysia 50728 Kuala Lumpur, Malaysia. Email: ksalina@iium.edu.my 
Keywords: Zakat, Poverty alleviation, Entrepreneurship, Bangladesh

JEL Classification: I32, L26, Z12

\section{INTRODUCTION}

It is estimated that around 3 billion people across the globe live in poverty with earnings of less than US\$1.25 a day (The World Bank, 2010). Even though the Muslim world possesses $70 \%$ of the world's energy resources and $40 \%$ of earth's natural resources, yet $35 \%$ of the world's poor populations live in countries with a Muslim majority (The World Bank, 2010; Laghari, 2013). These numbers indicate the extent of poverty across the world and a strong reflection about the failure of policy-makers to tackle this problem both globally and in the Muslim world.

For quite some time, aid has been the cornerstone of economic development programs, particularly for poverty alleviation and economic empowerment. During the last 50 years, more than US $\$ 1$ trillion in development assistance has been provided to poverty stricken countries, particularly in the African continent. However research suggests that aid recipients are worse off since aid has resulted in the poor to become poorer, and also caused economic growth to become slower (Gamieldien, 2010). Despite this predicament, aid remains the main tool for most poverty alleviation strategies. The recent financial crisis further point towards the need to mobilize local resources for the purpose of addressing the poverty issues as the amount of aid continues to shrink because of the economic and financial downturn in the rich countries as well as the diversion of aid to rising war affected areas. As the west and other donors are battling their own financial problems, the need to mobilize local resources to confront indigenous problems has become increasingly important.

Islam and development, contrary to typical belief, is perfectly compatible. Islam promotes equitable economic distribution and upholds the right of the poor through zakat and other forms of charity. These efforts, if properly implemented, allow the Muslims to come out of poverty and attain the objectives of the shariah (maqasid 
al-shariah) through promoting self-actualization goals which aim towards sustaining life, raising future progeny, developing human intellect, safeguarding faith and enjoying fruits of individual efforts through ownership (Pramanik, 2002).

In this regard, zakat, administered in effective ways, may prove to be a promising solution to the poverty alleviation problem, particularly in the Muslim countries. While in many Muslim countries zakat collection programs have been rather efficient, however, an effective zakat distribution program along with mechanisms to ensure sustainable benefits to the receivers, unfortunately, are not well developed. This effort is even more challenging in the context of today's complex economic situation which requires policy makers to find efficient ways to administer zakat for true growth and prosperity, compared to the situation when zakat was first introduced in Islam.

In the case of Bangladesh, an organization called Center for Zakat M anagement (CZM) has been w orking with the poor with zakat by encouraging entrepreneurship among the rural women. By building institutional capacity that offer seed capital along with other benefits like food, housing and water, sanitation and education, this new approach encompasses every need and deserves to be examined further.

This paper attempts to analyze the effectiveness of zakat-based program on the development of microenterprises and poverty alleviation. By focusing on the case study of CZM in Bangladesh, this study assesses the effectiveness of zakat on aspects such as income, household expense and asset accumulation based on the "before and after" approach. Groups comprising of poor individuals and families are given seed money and are encouraged to embark on small businesses according to their own liking. The groups are supervised for a period of a minimum of three years to ensure all individuals within the group are able to continue with their activities and graduate from poverty. Through this program, the groups are provided with zakat money as equity capital/seed money for businesses as well as funds for education, health and sanitation. 


\section{LITERATURE REVIEW}

\subsection{Zakat in Islam}

Literally, zakat has two meanings. First, it means "purity" and "cleanness" in which, by paying zakat, the wealth and indeed, the heart of the payers are cleansed and purified. Zakat purifies the heart of the payer and prepares him to sacrifice for the cause of Allah by removing stinginess (Shad, 1986). Second, zakat also means fertility or growth. The payment of zakat is designed to facilitate the growth of wealth and spirit among the zakat payers (Al-Q aradawi, 1973).

Essentially, zakat represents a levy on wealth that has been in possession of the Muslim faithful for one year subject to a minimum, or known as nisab, under which no zakat may be imposed (Kochuyt, 2009). The nisab according to Islamic theology is set at a low level which allows zakat to be imposed across a wide range of the population, thereby allowing the act of charity to be practiced not only by the wealthy class but other classes as well (Kochuyt, 2009).

The management and administration of zakat is primarily the responsibility of the state. However, after the fall of the Ottoman Empire in 1925, the governments of M uslim-majority countries ceased to administer this important institution and zakat became a personal obligation disbursed at a personal level. In the absence of the state to enforce the zakat obligations on the citizens, zakat collection shrunk over time resulting in only a small part of zakat to be paid by the Muslims within their community through personal and informal channel (Kahf, 2000).

The Quran specifies the categories of people who are entitled to receive zakat and leaves little ambiguity about these issues. According to the Quran (9:60), there are eight categories of people who are entitled to receive zakat proceeds, also known as the asnaf, namely:

(1) beggar (fuqara);

(2) poor (masakin);

(3) zakat collectors/officers (ameleen);

(4) a person who recently converted into Islam (muallafah);

(5) emancipated slave (fil-riqab);

(6) debtors (gharemeen);

(7) those who fight for Allah's cause (fi-sabilillah); and

(8) wayfarers (ibn al sabil). 
Looking back at the times when zakat was first introduced in Islam, there is strong indication that malullah or the wealth of Allah , which includes zakat, was also used for investment purposes and in commercial ventures where parts of the profits were paid to the BeitulMal. The use of zakat in a few instances was purely for profitmaking and not because the recipients were needy, involving the Khalifah at the time, who is Umar and his son Abdullah ibn Umar (Gamieldien, 2010). In this regard, the Muslim scholars opine that there is no injunction in the Quran or in the Sunnah, which prohibits zakat from being gainfully employed in order for it to grow even though orthodoxy opposes it (Gamieldien, 2010).

\subsection{Zakat, Entrepreneurship and Poverty Alleviation}

Islam does not only address the spiritual need of man, but also addresses all issues including social, political and economic issues, which is why Islam is often referred to as the complete way of life. Islam encourages the progress through the development of trade, commerce, industry and agriculture (Ubaid, 1975; Hoque, Mamun, \& Mamun, Dynamics and traits of entrepreneurship: an Islamic approach, 2010). Islam encourages trade and entrepreneurship by explicitly stating that 'business is lawful for you' (Quran 2:275) and discourages begging and being dependent on charity.

While entrepreneurship has high potential to improve the livelihood of the poor people, there seems to be a missing link between the desire to improve their living and the resources to embark on the business. In this regard, zakat has been playing an important role in reducing poverty and ensuring social development of the less privileged members of the society (Sulaiman, 2003). Zakat also helps to increase savings as it takes away a part of the precautionary savings (Choudhury, 1983).

Entrepreneurs are considered to be the engine of economic growth (Azim, 2011), who expedite economic development through their initiative (Matlay, 2005). According to Islam et al. (2011), the lack of seed money, and entrepreneur's inability to secure funds, is an important impediment to developing sufficient numbers of small, medium and large business enterprises. These are important deficiencies which inhibit the growth of enterprises which aggravates 
the poverty scenario present in many Muslim countries. Unfortunately many of these M uslim countries also have abundant natural resources; hence lack of wealth may not necessarily be the problem.

Obtaining capital for starting small businesses has always been one of the most challenging issues for potential entrepreneurs. Financial institutions are quite reluctant to deal with the microentrepreneurs as it is widely perceived that loans provided to this group presents a high risk of non-performance. If capital can be infused into micro-enterprises to start or to reinforce existing businesses, this would result in better prospect of success to be achieved by the entrepreneurs. The availability of the capital would greatly improve the operational efficiency and effectiveness, leading to improvement in the organization's performance, hence, alleviating poverty among them (Hadisumarto \& Ismail, 2010). Hadisumarto and Ismail (2010) went on to explain that capital is a succession of critical elements for any business to be successful, apart from labor expertise, technology and other inputs; the resulting growth in income, would, in turn, allow the poor to acquire the basic necessities in life, such as food, education and health.

According to Ahmad and Ahmad (2009), there is a great demand for Islamic financial products and services due to their overriding objective of social benefit maximization as opposed to profit maximization. To the poor, the capital provided by the authority is viewed as a motivational injection and opportunity for them to venture into businesses and avoid the hassle of having to secure loans from conventional banks by pledging collateral.

In the spirit of entrepreneurship and developing businesses, zakat as a source of seed money can be an important source especially in the case of growing small businesses. This may be successful if proper policies and strategies are devised by institutions that manage zakat, particularly in utilizing the zakat fund for developing entrepreneurship as a tool of poverty alleviation from the Muslim society. If this is successful, poverty can be reduced significantly from the society in general and M uslim society in particular.

There has been several studies estimating the potential of zakat collection in Bangladesh Based on the methodology employed by Kahf (1989), Bangladesh has the potential to generate a minimum zakat of 
$1.63 \%$ of its GDP to a maximum of $3.92 \%$ of its GDP (based on different opinions of jurists regarding zakatable assets) in 2010 (Islamic Social Finance Report 2014). According to Hassan and Khan (2007) Zakat money has the potential to fund government budgetary expenditures equivalent of 21 percent of ADP (annual development plan) in 1983-84 to 43 percent of ADP in 2004-2005.

Unfortunately most of the zakat money in Bangladesh is given out to people as money for consumption purposes rather than seed money for business capital. In a study conducted in Bangladesh on zakat payers and institutions that manage zakat, results indicate that only $18.5 \%$ of the total zakat handed out were given as seed money and $81.5 \%$ of zakat that was given out was used for consumption purposes (Hoque, Khan, \& M ohammad, 2015).

\subsection{Definition of Poverty}

Poverty is one of the major problems and is described as both a cause and an effect of many of the socio-economic evils of human society. It is defined as a condition of life characterized by hunger, disease, squalor, malnutrition, and mental and physical distress (Organization for Economic Co-operation and Development, 2001). Poverty causes social tensions, class-conflicts, and unrest, culminating in head-on confrontation between different social and political interests.

Some definitions emphasize upon considering mental, psychological and spiritual needs, not merely physical needs (Chapra, 2010). The World Bank, in particular, has recently revised its measurement of world poverty. Income shortfall of people with less than US\$1.25 a day (in 2005 U.S. dollars), and people with income shortfall of US $\$ 2.00$ a day are categorized as poor (Haughton \& Khandker, 2009). Other definitions define poverty as economic condition in which one is unable to enjoy a minimum standard of living.

At the UN's World Summit on Social Development, the 'Copenhagen Declaration' described poverty as "...a condition characterized by severe deprivation of basic human needs, including food, safe drinking water, sanitation facilities, health, shelter, education and information". Poverty defined by World Bank sums up 
as low income and inability to acquire the basic goods and services with following specifications: (i) low levels of health and education; (ii) poor access to clean water and sanitation; (iii) inadequate physical security; (iv) lack of voice; and (v) insufficient capacity and opportunity to better one's life (Haughton \& Khandker, 2009).

The concept of poverty has been classified into three different groups (Coudouel, Hentschel, \& Wodon, 2002) which are:

(i) Absolutely gauged: The absolute notion of poverty identifies the poor without reference to the situation of others in their society, and it refers to the "inability to attain a minimal standard of living".

(ii) Relative poverty: This has much to do with the issue of inequality (income and wealth distribution) and it identifies the poor relative to other segments of the society, i.e. relative to a comparator group.

(iii) Subjective poverty: This on the other hand, is a self-defined concept and it reflects the attitude and perception of a person towards what is regarded as minimum to meet basic needs, i.e. it compares "actual income against the earner's expectations and perceptions"".

The Grameen Bank defines poverty as those in poverty as people unable to feed themselves, get out of a constant repayment cycle, and produce a consistent dividend large enough to support a family with a home, food and water. It evaluates poverty level of the borrowers using ten indicators, including average cost of living, including basic utilities, average poverty rate within a designated community and the living conditions of those in poverty (Grameen Bank, 2014).

According to all these definitions, the criterion to distinguish the poor from the non-poor is through the construction of a border (known as poverty line), the inability to cross which is deemed the proof of one's poverty (Haughton \& Khandker, 2009).

\subsection{Concept of Poverty in Islam}

In Islam, poverty in broad sense entails lack of fulfillment of physical, intellectual, psychological spiritual needs to an optimum level. From economic point of view, Islam divides people only in two 
categories, the first category being people who have surplus income/asset to certain amounts/quantities after meeting all his/her annual expenses; and, second, those who fall short of their bare necessities. According the Prophet (pbuh), the real rich are those who are rich in mind. Imam Al-Shathibi categorized human needs in the following way: (a) Survival requirements (such as food, clothing, shelter, health care); (b) Developmental requirements (such as transport, education, fan, light, fridge); and (c) Aesthetic needs/beautification (such as art and design crafts, flower vase, gardening, showcase/piece) (Al-Raysuni, 2013).

\subsection{Poverty Situation in Bangladesh}

In Bangladesh, on the basis of head count ratio, absolute poverty stood at 40.4 percent in 2005 which moved down to 31.5 percent in 2010 (Bangladesh Bureau of Statistics, 2010). The World Bank released a poverty assessment report on Bangladesh in June 2013, which says the country is on track for reaching its poverty reduction target under the MDGs. The country is expected to halve its poverty headcount to 28.5 percent by 2013 . Johannes Zutt, World Bank Country Director for Bangladesh commented that "Against the odds, Bangladesh lifted 16 million people out of poverty in the last 10 years, and also reduced inequality; that is a rare and remarkable achievement".

World Bank has made six assumptions, which show that the poverty rate will be between 26.31 and 28.40 percent in 2013 with an annual average reduction of 1.73 percentage points. According to a survey of Bangladesh Bureau of Statistics, poverty declined 1.78 percentage points a year between 2000 and 2005. In the next five years, the reduction rate averaged 1.7 percentage points taking the number of poor people down to 31.5 percent of the population (The Daily Star, 2013).

\subsection{Women Entrepreneurship in Bangladesh}

Women empowerment and entrepreneurship is a key challenge facing developing countries like Bangladesh. Research indicates that a mere $10 \%$ of all entrepreneurs in South East Asia are women (Tambunan, 2009). The research also finds SMEs to be critically 
important to the economy as they represent almost $95 \%$ of all business firms. Ironically the role of women in heading SME's is quite low. Increased opportunities for women to participate in economic activities either as a successful entrepreneur or as a part of a SME in the role of an employee will undoubtedly help in poverty reduction.

Four factors help to explain why women entrepreneurs are in such short number. First of all literacy rates between men and women vary significantly, the gap being substantial in rural areas. Lack of education prevents women from seeking and utilizing opportunities. Second of all women in rural areas are trusted to carry out heavy house hold chores including child bearing. Women especially in rural areas cannot afford to recues themselves from the confines of their homes and operate businesses after taking care of their household responsibilities. Third of all cultural and religious beliefs discourage women to play the role of an active business persons resulting in women being confined to their homes (Tambunan, 2009).

Karim (2001) of the International Labor Office Geneva have highlighted important social and economic characteristics of women entrepreneurs in Bangladesh. The important characteristics include:

(i) Age: Women entrepreneurs on average are younger (33 years) than their male counterparts (33-37 years). Women entrepreneurs are relatively new, whilst men have been in this field far before women.

(ii) Education: Majority of women entrepreneurs are illiterate. About $42 \%$ of female entrepreneurs have less than 10 years in formal education.

(iii) Entrepreneurial experience: Male entrepreneurs start of their operations with more information and experience then women entrepreneurs. Typically men are more exposed to the outside world and have more contacts whereas women have little such exposure. An average year of work experience in similar businesses for males is 4.9 years and for females is 0.8 years.

(iv) Enterprise location: Majority of the women-headed enterprises are home-based $(86 \%)$ compared to $39 \%$ among male-headed. Women entrepreneurs tend to think of their businesses as an extension to their family responsibility, whereas men think of their business as a separate venture. 


\section{BRIEF OVERVIEW OF CZM JEEBIKA KARNAPHULI PROJECT}

The Jeebika Karnaphuli project is a zakat-based poverty alleviation project. The project focuses on sustainable graduation of 450 impoverished families living in rural Bangladesh. The project was launched in February 2011 with zakat and financial support of leading businesses and plans to end by December 2015.

The project aims at improving the lives of extremely poor families by encouraging entrepreneurship especially among women. Most of the families live well below the poverty line in alarming rural conditions with limited logistic facilities like electricity, running water, roads and basic facilities such as education and health care. The project is unique as it aims to address not only the financial shortcomings of the families but also the social shortcoming that the families face which continue to limit their growth.

The Village Organization (VO) acts as the center for all activities comprising of 30 families of the same neighborhood. The project currently has 15 VOs out of which 11 works with bamboo/cane and the rest are involved in fishing activity.

Each family is represented by the female member of the household making her the principal beneficiary. Each VO elects its own management committee which is responsible for organizing weekly meetings, managing the fund and arranging community activities under the supervision of CZM. Rahman (2015) describes the project cycle in the following manner (Table 1).

Beneficiaries are provided with a five-fold stake in the project:

(i) Equity capital: Zakat allocated for individual families are accumulated to form the group's equity capital held in a bank account which is owned and operated by the members of the group.

(ii) Micro loans: The beneficiary group's pooled equity capital forms a revolving fund to which every member has access. Each member of the group has the option for applying for a loan which has to be used to initiate a micro enterprise. The loans are being sanctioned from the equity capital owned by the group members, which makes it different from a conventional loan where the lender and borrower are two different people. 
(iii) Group profit: Profit accrued from the service charge charged for the micro-loans accumulate in the group bank account. The profit is equally distributed amongst all members of the group.

(iv) Social sector support: Covers support for education, health, water, sanitation and home gardening.

(v) Capacity building: Covers support for training on management, leadership and enterprise skills

Table 1.

Project Cycle

\begin{tabular}{|c|c|c|}
\hline Phase & Step & Activity \\
\hline $\begin{array}{l}\text { Inception } \\
\text { (6 months) }\end{array}$ & Step 1 & $\begin{array}{l}\text { - Preparatory works by implementing agency } \\
\text { (CZM ): Situation analysis, Beneficiary selection, } \\
\text { Capacity building strategy finalization }\end{array}$ \\
\hline \multirow{6}{*}{$\begin{array}{l}\text { Implementation } \\
\text { ( } 3 \text { years) }\end{array}$} & Step 2 & $\begin{array}{l}\text { - Formation of Village Organizations (VO) i.e. } 30 \\
\text { member group of selected beneficiaries and } \\
\text { formation of management committee }\end{array}$ \\
\hline & Step 3 & $\begin{array}{l}\text { - Capacity building of VOs for multi-purpose } \\
\text { weekly meetings, opening of group bank } \\
\text { account, promotion of savings habit, preparation } \\
\text { of loan applications, loan disbursement and } \\
\text { installment collection, accounts maintenance, } \\
\text { dealing with bank }\end{array}$ \\
\hline & Step 4 & $\begin{array}{l}\text { - Opening of bank account in the name of VO } \\
\text { with the pooled zakat for each beneficiary family }\end{array}$ \\
\hline & Step 5 & - Operation of revolving fund \\
\hline & Step 6 & $\begin{array}{l}\text { - Skill development training on productivity } \\
\text { improvement and market linkage for the selected } \\
\text { livelihoods }\end{array}$ \\
\hline & Step 7 & $\begin{array}{l}\text { - Implementation of complementary community } \\
\text { activities on water, sanitation, education and } \\
\text { health }\end{array}$ \\
\hline $\begin{array}{l}\text { Exit } \\
\text { (6 months) }\end{array}$ & Step 8 & $\begin{array}{l}\text { - Preparation of exit strategy } \\
\text { - Transfer of all responsibilities to VOs }\end{array}$ \\
\hline
\end{tabular}

\section{EM PIRICAL MODELS AND VARIABLES}

Previous studies have used different techniques such as descriptive analysis, ordinary least square (OLS), weighted least square (WLS), linear programming (LP), and simultaneous equation systems (SES) in order to estimate the effect of Islamic social finance on the various outcomes such as income, consumption and saving etc. This study has used OLS estimation technique for the study. Three 
econometric models have been used in this paper to assess the effectiveness of zakat provided as seed money towards the success of microenterprise. Three variables have been chosen to measure the success of microenterprises, namely income, fixed assets, and household expenditures. This research also focuses on five (independent) variables which are expected to have significant influence on the microenterprises performance. The empirical models are presented below:

The first model is presented as Equation 1:

Change in income $=f($ Age + Education + Amount of Zakat $($ Log $)$

$$
+ \text { Type of Business + Family Size) }
$$

The second model is presented as Equation 2:

Change in fixed asset $=f($ Age + Education + Amount of Zakat

$$
(\text { Log })+\text { Type of Business + Family Size })
$$

The third model is presented as Equation 3:

Change in household's expenditure $=f($ Age + Education +

Amount of Zakat(Log) + Type of Business + Family Size)

Table 2.

Description of Determinants of Success of M icroenterprises

\begin{tabular}{|l|l|}
\hline \multicolumn{1}{|c|}{ Variable Name } & \multicolumn{1}{c|}{ Description } \\
\hline Change Income & $\begin{array}{l}\text { Income of microenterprise per month in } \\
\text { Bangladesh Taka before and after receiving zakat }\end{array}$ \\
\hline Change Fixed Assets & $\begin{array}{l}\text { The total amount of fixed assets in Bangladesh } \\
\text { Taka before and after receiving zakat }\end{array}$ \\
\hline $\begin{array}{l}\text { Change Household } \\
\text { Expenditures }\end{array}$ & $\begin{array}{l}\text { The total amount of expenditure per month in } \\
\text { Bangladesh Taka before and after receiving zakat }\end{array}$ \\
\hline Age & Actual age of respondents \\
\hline Educational background & $\begin{array}{l}\text { Categorical variable consists of 1: uneducated, 2: } \\
\text { primary school, 3: secondary, 4: tertiary }\end{array}$ \\
\hline Amount of Zakat (log) & $\begin{array}{l}\text { The amount of zakat received transformed into } \\
\text { log amount }\end{array}$ \\
\hline Type of Business & Dummy variable for type of business \\
\hline Family Size & The number of family members \\
\hline
\end{tabular}

Based on previous studies such as Chittithaworn, Islam, Keawchana, and Yusuf (2011) as well as Rahman, Jafrullah, and Islam (2008), this research stresses on three financial measurements, namely 
income, fixed assets, and household expenses. There are three factors employed to measure the effectiveness of zakat on the success of microenterprises. First, financing is thought to have a big impact on the micro entrepreneurs in enlarging their business activities. Second, the characteristics of the entrepreneur are also believed to influence the performance of microenterprise. The characteristics of the entrepreneur typical used to assess are age, educational background and family size. Finally the kind of business is also taken as important factors in contributing towards the success and failure of microenterprises. There are three regressands used here to measure the effectiveness of zakat, namely:

\section{(i) Income of Microenterprise}

Income is an important indicator to assess the economic performance of a microenterprise (Faridi, 2011; Rahman, Jafrullah, \& Islam, 2008). Income can either indicate use of income or the flow of income. Use of income highlights the expenditure and investment activities of household members. $M$ eanwhile, the flow of income emphasises income from the sale of products and services. This study uses the flow of income from the sale of goods and services. It uses the gross income of the microenterprise from the flow of income generated from sales of goods and services as the dependent variable.

\section{(ii) Fixed Assets}

Change in enterprises' fixed assets is the second dependent variable. By receiving Zakat microenterprises are able to buy fixed assets to increase their production and expand their business activities. Apart from income, fixed assets are one of the best indicators for tracking changes in enterprise welfare and could be considered as a measurement of success (McPherson, Molina, \& Jewell, 2010).

(iii) Change of Household's Expenditure

Household expenditure is one of the measurements of success of microenterprises (Ngaosi \& Navarro, 2007; Rahman, Jafrullah, \& Islam, 2008). Household expenditure consists of both food and non-food expenditure, including education, clothing, house, health and transportation. 
The three factors which represent the independent or explanatory variables in this study are financing, entrepreneur characteristics and firm's characteristics. Previous studies highlight financing which impacts the performance of microenterprise (Faridi, 2011; Selamat, Razak, Gapor, \& Sanusi, 2011; Bhasin \& Akpalu, 2001; Nawai \& Shariff, 2010; Rahman, Jafrullah, \& Islam, 2008). Financing consists of the amount of zakat received, which reflects the amount of zakat received by the poor. It is assumed that the amount of zakat could be one of the most important factors for of the success of microenterprise (Nawai \& Shariff, 2010).

Entrepreneur characteristics has been used in many previous literature to examine the success of enterprise (Faridi, 2011; Reijonen, 2008; Selamat, Razak, Gapor, \& Sanusi, 2011; Bhasin \& Akpalu, 2001; Chittithaworn, Islam, Keawchana, \& Yusuf, 2011; Halim, M uda, Amin, \& Salleh, 2012); (Daou \& Karuranga, 2012; Tovstiga \& \& Tulugurova, 2007). This study selects four variables of entrepreneur characteristics assuming that these variables will have a positive influence on the success of microenterprises. The variables selected from previous literature consist of the following:

(i) Age of Member (Age): Age as a characteristics is widely used in determining the success of microenterprises (Bhasin \& Akpalu, 2001; Halim, Muda, Amin, \& Salleh, 2012; Daou \& Karuranga, 2012; Nawai \& Shariff, 2010; Rahman, Jafrullah, \& Islam, 2008). Previous studies suggest that older entrepreneurs are more likely to succeed perhaps due to greater experience.

(ii) Education: Studies in the past have recognized educational background as an important entrepreneur characteristics that affect the success of an enterprise (Bhasin \& Akpalu, 2001; Halim, Muda, Amin, \& Salleh, 2012; Daou \& Karuranga, 2012; Tovstiga \& Tulugurova, 2007; Nawai \& Shariff, 2010; Rahman, Jafrullah, \& Islam, 2008). Education is a categorical variable with the following categories: 1: uneducated; 2: primary school; 3: high school; 4: senior high school; and 5: diploma/bachelor.

(iii) Family Size: Many studies conducted in the past find age of the family head and family size to be an important factor in household economic development (Girish \& Mehta, 2003; Rahman, Jafrullah, \& Islam, 2008). According to Latif (2002), 
family size influences consumption and calorie intake of rural Bangladeshi households.

Studies in the past have considered a firm's characteristics as factors determining the success of a microenterprise (Ngaosi \& Navarro, 2007; Selamat, Razak, Gapor, \& Sanusi, 2011; Nawai \& Shariff, 2010; Chittithaw orn, Islam, Keawchana, \& Yusuf, 2011; Daou \& Karuranga, 2012). This study uses type of business as firm characteristics.

(iv) Type of Business (TOB): This is a dummy variable that consists of several categories. Typically zakat recipients are involved in three types of microenterprises which are small businesses, fishing equipment manufacturing and cottage industry.

\section{DATA AND RESEARCH METHODOLOGY}

\subsection{Survey Design and Data Collection}

The survey design executed from January 2015 to June 2015 in Chittagong city, Bangladesh. This study concentrates specifically on micro entrepreneurs receiving zakat obtained from CZM. Exactly 420 households are chosen for the study.

This survey was conducted by 10 surveyors. All surveyors received adequate training on how to conduct the survey. The formula used to calculate the sample size is as follows:

$$
n_{o}=\frac{Z^{2} p q}{e^{2}}
$$

where:

$n_{o}=$ the sample size

$Z^{2}=$ the abscissa of the normal curve that cuts off an area at the tails ( 1 - equals the desired confidence level, e.g. 95\%), the value found in the statistical tables, which contains the area under the normal curve

$e=$ the desired level of precision

$p=$ the estimated proportion of an attribute that is present in the population

$q=1-p$ 
This study assumes that there is a large population of CZM clients. The variability in the proportion of micro-entrepreneurs who received zakat, however, is not known. This study assumes $p=0.5$ (maximum variability). The resulting sample size is demonstrated below:

$$
n_{o}=\frac{Z^{2} p q}{e^{2}}=\frac{(1.96)^{2}(0.5)(0.5)}{(0.5)^{2}}=385 \text { respondents }
$$

In accordance with the calculation result, more than 400 respondents were selected for this study from among microentrepreneurs who received zakat from CZM .

\subsection{Method: Before and After Approach}

The before and after method has been used to calculate the effectiveness of zakat on micro entrepreneurs by measuring change in income, fixed assets, and household expenses before and after receiving zakat. Concentrating on changes in the dependent variable or known as "before and after" or "differences" caused the unobserved factors constant which is varied from one state to other states but do not alter over time inside the state. SPSS 17 is employed to measure the effectiveness of zakat on microenterprise performance.

\section{RESULTS AND DISCUSSION}

\subsection{Descriptions of Respondents}

The study was conducted to assess the impact of zakat on poor women micro entrepreneurs. Research suggests that apart from economic factors, demographic factors also play an important factor in economic empowerment and poverty alleviation. Due to this reason it is important to understand both the economic and demographic criteria of the women respondents to fully assess the change brought about before and receiving zakat.

\section{(i) Age of the Clients}

Women who have received zakat from CZM are aged between 20 to 70 years old. Teenagers aged below 20 were not given zakat to start microenterprises. Apart from teenagers, the wide 
dispersion of age indicates that both the young and the old have received zakat from CZM. How ever the majority of zakat receivers $(67 \%)$ fall within the 30 - 50 years age group. This age group represents an age consisting of women who have a bit of experience and are able to bear the physical and mental stress of running an enterprise. Approximately $21 \%$ of the recipients are aged 50 to 70 years representing an older age group who by comparison are fewer in number. The remaining $11 \%$ fall within the age of 20 to 29 years.

\section{(ii) Family Size}

About $13 \%$ of the micro-entrepreneurs have a small family consisting of two members. Medium family size comprising of 4 members make up of $49 \%$ of the respondents. The remaining $38 \%$ of the respondents have a large family consisting of more than 5 family members.

\section{(iii) Education}

Almost $57 \%$ of the micro entrepreneurs were found to be illiterate. Amongst the remaining entrepreneurs, 37\% had primary education or went to school till grade 5 . Only $6 \%$ had high school degrees which is also the highest level of education in this group.

\section{(iv) Marital Status}

Almost all respondents or $98 \%$ were married. The remaining $2 \%$ were either divorced or widowed. CZM may have intentionally targeted married women as they are less likely to migrate from their current residence. Less mobility allows greater supervision and monitoring by CZM .

\section{(v) Type of Business}

Micro-entrepreneurs have set up 3 types of business which is reflective of the rural nature of the project area. Nearly $62 \%$ of the zakat recipients are engaged in cottage industry activities, a type of business which is easily manageable by women entrepreneurs. $26 \%$ of the entrepreneurs have made investments in supplying equipment for fishing. The remaining $12 \%$ have set up small shops with the zakat money that they received. It should, however, be noted that multiple occupations are common. In terms of the occupational identity of the family, 
these fall into three broad categories - cottage industry (bamboo/cane), fishing and a residual business category.

\section{(vi) Investment Sizes}

Investment sizes of the micro entrepreneurs ranged from BDT 40,000 to 75,000 over a period of four years. About $8 \%$ of the investments can be considered to be as low investments which range between 40,000 to 50,000 BDT. Moderate investments ranging from BDT $50,001-60,000$ are about $27 \%$. Majority of the investments can be considered as large investment ranging between 60,001 BDT to 75,000 BDT. This indicates that micro entrepreneurs have demonstrated their willingness to take risks and invest relatively large sums of money in their enterprises.

Table 3 shows the zakat recipients performance before and after in terms of income, fixed asset and household expenditure.

Table 3.

Performance of M icroenterprises Receiving Zakat in Nominal Terms (in BDT)

\begin{tabular}{|c|c|c|c|c|c|c|}
\hline & \multicolumn{2}{|c|}{ Monthly Income } & \multicolumn{2}{|c|}{ Fixed Assets } & \multicolumn{2}{|c|}{$\begin{array}{l}\text { Household } \\
\text { Expenditure }\end{array}$} \\
\hline & Before & After & Before & After & Before & After \\
\hline $\mathrm{N}$-Valid & 420 & 420 & 420 & 420 & 420 & 420 \\
\hline $\mathrm{N}-\mathrm{M}$ issing & 0 & 0 & 0 & 0 & 0 & 0 \\
\hline Mean & $3,128.26$ & $9,763.27$ & $4,221.00$ & $21,838.33$ & $3,685.96$ & $8,257.50$ \\
\hline Median & $3,000.00$ & $9,275.00$ & $4,000.00$ & $21,100.00$ & $3,500.00$ & $7,925.00$ \\
\hline Std. & $1,229.727$ & $2,919.626$ & 932.893 & $8,401.314$ & $1,500.547$ & $2,641.079$ \\
\hline Deviation & & & & & & \\
\hline Minimum & 1,000 & 4,350 & 2,000 & 1,700 & 1,000 & 3,137 \\
\hline Maximum & 9,100 & 20,270 & 9,000 & 90,000 & 9,400 & 17,980 \\
\hline
\end{tabular}

The table shows that monthly income of zakat recipients have improved significantly after receiving zakat from CZM . Considering the mean income the average monthly income of a zakat recipient was only 3,128.26 BDT per month before receiving zakat, this has increased to 9,763.27 BDT per month four years after receiving zakat from CZM.

According to the table there is an equally significant change in the increase in possession of fixed assets. The amount of average fixed assets of zakat recipients was 4,221.00 BDT which increased to $21,838.33$ BDT. This indicates that on average the micro- 
entrepreneurs have spent a significant amount of their increased income to purchase fixed assets.

Household expenditures have increased over time but that increase is not as large as the change in income or a change in fixed assets. This may indicate that micro entrepreneurs have been conservative in spending their increased income on house hold expenses in comparison to acquiring fixed assets. This is a good indicator since house hold expenditure is an unproductive expense, which does not generate further revenue, whereas fixed assets provide an opportunity for income increase and capital gains.

Table 4.

Performance of Microenterprises Receiving Zakat in Real Terms (Comparing Means in BDT)

\begin{tabular}{llclccc}
\hline & \multicolumn{2}{c}{ Monthly Income } & \multicolumn{2}{c}{ Fixed Assets } & \multicolumn{2}{c}{$\begin{array}{c}\text { Household } \\
\text { Expenditure }\end{array}$} \\
\cline { 2 - 7 } & Before & After & Before & After & Before & After \\
\hline M ean & $2,825.89$ & $7,216.02$ & $3,813.01$ & $16,140.67$ & $3,329.68$ & $6,103.10$ \\
Change & & $4,390.13$ & & $12,327.66$ & & $2,773.42$ \\
\hline
\end{tabular}

With high inflation rates in Bangladesh, income, fixed assets and household expenditure over time may not accurately represent the actual change. So it is necessary to compare the means in real terms to assess actual growth after it has been adjusted for inflation. According to the results in table 4 there is a real growth in monthly income, accumulation of fixed assets and household expenditure before and after receiving Zakat from CZM .

The following section highlights empirical results from the analysis of the determinants of the success of microenterprises receiving zakat funds from CZM in terms of income, fixed assets, and household expenditure. 
Table 5.

Results from Regression 1 - Change in Income

\begin{tabular}{lrrr}
\hline & \multicolumn{3}{c}{ Change in Income } \\
Variables & Coefficient & Standard Error & Significance \\
\hline Age & 26.844 & 14.120 & $0.057^{* * *}$ \\
Education & 341.974 & 223.856 & 0.127 \\
Type of business & 1102.653 & 191.418 & $0.00^{*}$ \\
Amount of zakat & 4546.868 & 736.380 & $0.00^{*}$ \\
Family size & -286.900 & 88.551 & $0.001^{*}$ \\
Intercept & -42641.360 & 7817.722 & \\
R Square & 0.173 & & \\
Durbin Watson & 1.919 & & $0.00^{*}$ \\
F statistic & 17.334 & & \\
\hline Notes: $*$ Significance at $0.01, * *$ Significance at $0.05, * * *$ Significance at 0.1. \\
Regression (1), (2), and $(3)$ indicate having heteroscedasticity and are free from \\
autocorrelation
\end{tabular}

Regression (1) focuses on the factors that determine the success of microenterprises that has received zakat funds which has been measured by the change in income. In this model, Age, Education, Type of Business, Zakat amount and Family Size have been considered to assess the change in come. Apart from Education, all variables have a positive and significant influence on the income from microenterprises.

Entrepreneur characteristics in terms of age indicate a positive relationship with the change in income of microenterprises. This suggests that with the increase in age, micro entrepreneurs acquire more experience which assists them in earning more from their investment. Several research have established age as an important variable to asses influence on income, savings and agricultural production (Khandaker, 2000)

Results also show that the size of the family had a negative and significant influence on the income of the entrepreneur. This result indicates bigger families are less likely to have a higher income in comparison to families with fewer members. Previous results conducted by Mahmood (2006) contradict this claim.

The amount of zakat money invested by micro entrepreneurs had a positive and significant influence on the change in their income. 
This fund which is unlike a loan has given poor women an opportunity to start their own businesses and engage in economic activities out of the household.

This proves that financing is an important factor in determining the success of microenterprises, which is similar to the findings of other studies (Faridi, 2011; Bhasin \& Akpalu, 2001; Nawai \& Shariff, 2010). In contrast, several studies indicate that financing is not considered a vital factor in determining the success of microenterprises (Ngaosi \& Navarro, 2007; McPherson, Molina, \& Jewell, 2010). The type of business also has had a postive influene on the increase in income.

Table 6.

Results from Regression 2 - Change in Fixed Assets

\begin{tabular}{lrrc}
\hline & \multicolumn{3}{c}{ Change in Fixed Assets } \\
Variables & Coefficient & Standard Error & Significance \\
\hline Age & -14.533 & 42.274 & 0.731 \\
Education & 100.587 & 670.227 & 0.881 \\
Type of business & 2778.052 & 573.108 & $0.00^{*}$ \\
Amount of zakat & 3155.911 & 2204.733 & .153 \\
Family size & -913.468 & 265.123 & $0.001^{*}$ \\
Intercept & -14471.382 & 22622.233 & \\
R Square & .084 & & \\
Durbin Watson & 2.105 & & $0.00^{*}$ \\
F statistic & 7.584 & & \\
\hline
\end{tabular}

Notes. $*$ Significance at $0.01, * *$ Significance at $0.05, * * *$ Significance at 0.1 . Regression (1), (2), and (3) indicate having heteroscedasticity and are free from autocorrelation.

Regression 2 focuses on the factors that determine the change in fixed assets of micro entrepreneurs who have received zakat. Results indicate that factors such as zakat amount, age, and education have no significant impact on the change in fixed assets of microenterprises. The only factor that influences change in fixed assets is the type of business and the family size of the entrepreneur. This result indicates that when it comes to the acquisition and utilization of fixed assets, factors other than the ones mentioned play an important role. This again reinforces the findings of (Ngaosi \& Navarro, 2007, McPherson, Molina, \& Jewell, 2010) which state that financing play a limited role in the success of microentrepreneurs. 
Table 7.

Results from Regression 2 - Change in Household Income

\begin{tabular}{lrrr}
\hline Variables & \multicolumn{3}{c}{ Change in Household Expenditure } \\
& Coefficient & Standard Error & Significance \\
\hline Age & 39.418 & 12.730 & $0.002^{* *}$ \\
Education & 259.959 & 201.821 & 0.198 \\
Type of Business & 737.040 & 172.576 & $0.000^{*}$ \\
Amount of zakat & 3847.908 & 663.897 & $0.000^{*}$ \\
Family size & -227.377 & 79.835 & $0.005^{*}$ \\
Intercept & -36589.994 & 6812.086 & \\
R Square & .141 & & \\
Durbin Watson & 1.774 & & \\
F statistic & 13.563 & \\
\hline Notes. ${ }^{*}$ Significance at $0.01, * *$ Significance at $0.05,{ }^{* * *}$ Significance at 0.1 . Regression
\end{tabular}

(1), (2), and (3) indicate having heteroscedasticity and are free from autocorrelation

Regression 3 looks into the factors that influence a change in household expense of micro entrepreneurs. Household expenditure comprises of expenditure on food items and non-food items. This study assesses the factors that influence the change in total house hold expenditure.

The results indicate the amount of zakat, age, type of business and family size all have significant influence in the change in house hold expense. With increased investment from zakat and increased income, it is highly likely that households will increase both their food and non-food items indicating an increase in living standards. Family size also has a negative influence in increased house hold expenditure. Results indicate that house hold income is significantly less for large families compared to families with fewer members. Previous studies conducted on similar issues contradict this claim (Rahman, Jafrullah, \& Islam, 2008). Education level of the entrepreneur on the other hand plays no significant role in influencing change in house hold expense.

The R-square values of $0.173,0.084$ and 0.141 in regressions 1,2 and 3 are low. However this low value of $R$ square has limited impact on this study as the cross sectional data is highly varied (Gujarati, 2003). 


\section{CONCLUSION AND RECOMMENDATION}

Zakat, as a tool for economic empowerment can play a significant role in building microenterprises owned by the financially disfranchised in developing countries like Bangladesh. With a large number of poor people, zakat may be an alternative source of finance available locally and not dependent on foreign sources. In this particular case zakat can have significant positive influence in generating income from creating microenterprises and increasing household income and consumption.

Zakat can also pay an important role in the economic empowerment of women. Women entrepreneurship faces many challenges in a developing country in Bangladesh. But given the opportunity and necessary resources, women entrepreneurs can succeed just as well as their male counterparts. By encouraging women to participate in economic activities, a large pool of hard working and determined can be encouraged to better themselves and improve the lives of the members of their households.

Focus should now be given towards assisting the poor with zakat and supporting them to build enterprises which should be sustainable. All stakeholders including the government and NGO's may find benefit in putting efforts in mobilizing and distributing zakat institutionally and efficiently. Poverty is a complex problem and should be addressed from various angles including religious and moral angles and not just an economic problem. Proposing zakat for building entrepreneurship amongst poor rural women may be one solution to this problem and deserves more attention.

There are a few limitations of this study. The respondents of this survey all live in the same area in Chittagong of Bangladesh, and being of a particular area, the results may not be generalized for the whole of Bangladesh. Future studies covering other similar projects spread across the country may be conducted the results of which can be generalized for the entire country.

Apart from the zakat received as seed money for starting small businesses, the recipients also received zakat for education, health and other emergency purposes which may have indirectly impacted their economic impact. A broader study taking these factors into 
consideration should be conducted to accurately measure the impact of zakat which was provided as seed money and zakat which was provided for consumption purposes. 


\section{REFERENCES}

Ahmad, A. U., \& Ahmad, A. R. (2009). Islamic microfinance: The evidence from Australia. Humanomics, 25(3), 217-235.

Al-Qaradawi, Y. (1973). Fiqh al Zakah. Beirut: Mu'assasat al Risalah.

Al-Raysuni, A. (2013). Imam Al-Shatibi'S theory of the higher objectives and intents of islamic law. London: International Institute of Islamic Thought (IIIT).

Azim, M. T. (2011). Entrepreneurship development in Bangladesh. Dhaka: UGC.

Bangladesh Bureau of Statistics. (2010). Household expenditure survey (HEIS). Dhaka: Author.

Bhasin, K. V., \& Akpalu, W. (2001). Impact of microfinance enterprises on the efficiency of microenterprises in Cape Coast (IFLIP Research Paper 01-5). International Labour Organization.

Chapra, M. U. (2010). Islamic perspective on poverty alleviation. Jeddah: Islamic Research and Training Institute.

Chittithaworn, C., Islam, M. A., Keawchana, T., \& Yusuf, D. H. (2011). Factors affecting business success of small $\&$ medium enterprises (SM Es) in Thailand. Asian Social Science, 7(5), 180-190.

Choudhury, N. (1983). Aggregate demand and al-Zakah. Thoughts on Economics, 4(9), 1-8.

Coudouel, A., Hentschel, J. S., \& Wodon, Q. T. (2002). Poverty measurement and analysis. Wahington, DC: The World Bank.

Daou, A., \& Karuranga, E. (2012). Retrieved September 10, 2015, from http://www.wbiconpro.com/218-Alain.

Faridi, R. (2011). Determinants of women's success in microcredit program. The Journal of Developing Areas, 45, 167-189.

Gamieldien, S. M. F. (2010). Between the desire for change and the need for permanency. In A. G. Ismail, M. E. M. Hasan, N. Ismail, $\&$ S. Shahimi (Eds.), Seventh International Conference - The 
Tawhidi Epistemology: Zakat and Waqf Economy (pp. 44-51). Bangi, Selangor.

Girish, M., \& Mehta, P. (2003). Crop diversification: An empirical analysis on Kangra farms of Himachal Pradesh, India. AsiaPacific Journal of Rural Development, 13(2).

Grameen Bank. (2014). Retrieved March 17, 2014, from Grameen Bank website: http://www.grameen-info.org

Gujarati, N. D. (2003). Basic econometrics (4 ${ }^{\text {th }}$ ed.). M cGraw Hill.

Hadisumarto, W. B., \& Ismail, A. G. (2010). Improving the effectiveness of islamic micro-financing: Learning from BMT experience. Humanomics, 26(1), 65-75.

Halim, M. A., Muda, S., Amin, W. A., \& Salleh, A. M. (2012). The significance difference on entrepreneurial profile toward entrepreneurial personality in micro and small business: M alaysia Creative Industry. Asian Social Sciences, 8(3), 236-245.

Hassan, M. K., \& Khan, J. M. (2007). Zakat, external debt and poverty reduction strategy in Bangladesh. Journal of Economic Cooperation, 28(4), 1-38.

Haughton, J., \& Khandker, S. R. (2009). Handbook on poverty and inequality. Washington, DC: The World Bank.

Hoque, N., Mamun, A., \& Mamun, A. M . (2010). Dynamics and traits of entrepreneurship: An islamic approach. World Journal of Entrepreneurship, Management and Sustainable Development, 10(2), 128-142.

Hoque, N., Khan, A., \& Mohammad, D. (2015). Poverty alleviation by zakah in transitional economy: A small business entrepreneurial framework. Journal of Global Entrepreneurship Framework, 5(7), 1-20.

Islamic Research and Training Institute. (2014). Islamic social finance report 2014. Jeddah: Author.

Kahf, M. (2000). Zakah management in some muslim societies. Jeddah: Islamic Development Bank Islamic Research and Training Institute. 
Kahf, M. (1989). Zakat: Unresolved issues in the contemporary fiqh. Journal of Islamic Economics, 2(1), 1-22.

Karim, N. A. (2001). Jobs, gender and small enterprises in Bangladesh: Factors affecting women entrepreneurs in Bangladesh (SEED Working Paper No.14). International Labour Office Geneva.

Khandaker, S. R. (2000). Savings, informal borrowing, and microfinance. The Bangladesh Development Studies, 26(2), 49-78.

Kochuyt, T. (2009). God, gifts and poor people: On charity in Islam. Social Compass, 56 (1), 98-116.

Laghari, J. (2013, June 15). The express tribune. Retrieved September 8, 2015, from http://tribune.com.pk/story 563435/gdp-40pc-ofmuslim-states-population-fall-below-poverty-line/

Mahmood, T. (2006). Effectiveness of microcredit for poverty alleviation under agricultural intensification projects in Bangladesh (PhD Thesis). School of Graduate Studies, University Putra Malaysia, Malaysia.

Matlay, H. (2005). Entrepreneurship education in UK business schools: conceptual, contextual and policy considerations. Journal of Small Business and Enterprise Development, 12(4), 627-643.

McPherson, A. M., Molina, J. D., \& Jewell, T. R. (2010). The determinants of the growth of microenterprises in Central Mexico: Evidence from a survey in Toluca. Canadian Journal of Development Studies, 31, 223-252.

Nawai, N., \& Shariff, M. N. (2010). Determinants of repayment performance in microcredit programs: A review of literature. International Journal of Business and Social Science, 1(2).

Ngaosi, B. L., \& Navarro, M. G. (2007, October). The characteristics of selected microentrepreneurial ventures: $A$ vital tool towards success. Paper presented at $10^{\text {th }}$ National Convention on Statistics (NCS), 1-2 October 2007, EDSA Shangri-La Hotel.

Organization for Economic Co-operation and Development. (2001). The DAC guidelines poverty reduction. France: OECD Publication Service. 
Pramanik, A. H. (2002). Islam and development revisited with evidence from Malaysia. Islamic Economic Studies, 10(1), 39-74

Rahman, D. M. (2011). Islamic microfinance: A tool for poverty alleviation. Saarbrucken, Germany: LAP LAMBERT Academic Publishing.

Rahman, M. M., Jafrullah, M., \& Islam, A. T. (2008). Rural development scheme of Islami Bank Banggladesh Limited (IBBL): Assessment and challenges. IIUM Journal of Economics and Management, 16(2), 139-163.

Reijonen, H. (2008). Understanding the small business owner: What they really aim at and how this relates to firm performance: A case study in North Karelia, Finland. Management Research News, 31, 616-629.

Selamat, N.H., Razak, R.R., Gapor, S.A., \& Sanusi, Z.A. (2011). Survival through entrepreneurship: Determinants of successful microenterprises in Balik Pulau, Penang Island, Malaysia. British Journal of Arts and Social Sciences, 3(1), 23-27.

Shad, A.R. (1986). Zakat and Ushr. Lahore: Kazi Publications.

Sulaiman, M. (2003). The influence of riba and zakat on islamic accounting. Indonesian Management Accounting Review, 2(2), 149-167.

Tambunan, T. (2009). Women entrepreneurship in asian developing countries: Their development and main constraints. Journal of Development and Agricultural Economics, 1(2), 27-40.

The Daily Star. (2013). Our poverty reduction success. Dhaka: The Daily Star.

The World Bank. (2010). The world bank. Retrieved September 10, 2015, from The World Bank: http://www.worldbank.org

Tovstiga, G., \& Tulugurova, E. (2007). Intellectual capital practices and performance in russian enterprises. Journal of Intellectual Capital, 8(4), 695-707.

Ubaid, A. (1975). Kitabul amwal. Egypt: Darul Fikr. 
258 Journal of Islamic Monetary Economics and Finance, Vol. 1, No.2, February 2016

This page is intentionally left blank 